\title{
Development of Loxosceles intermedia Mello-Leitão (1934) (Araneae, Sicariidae) genital tract
}

\author{
Margraf, A. ${ }^{a}$, Costa-Ayub, CLS. ${ }^{a *}$, Okada, MA. ${ }^{b}$, Gomes, JR. ${ }^{a}$, \\ Ortolani-Machado, CF. ${ }^{b}$ and Soares, MAM. ${ }^{a}$ \\ ${ }^{a}$ Departamento de Biologia Estrutural, Molecular e Genética, Universidade Estadual de Ponta Grossa - UEPG, \\ Av. Carlos Cavalcanti, 4748, Campus Uvaranas, CEP 84030-900, Ponta Grossa, PR, Brazil

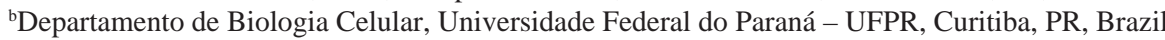 \\ *e-mail: clscayub@uepg.br
}

Received -July 27, 2010 - Accepted August 19, 2010 - Distributed August 31, 2011

(With 7 figures)

\begin{abstract}
We examined the post-embryonic development of the male and female genital apparatus of the brown spider, Loxosceles intermedia. The development of the genital apparatus for both sexes begins with the appearance of inner structures. In the male genital apparatus, formation of the testes occurs first, followed by differentiation of the duct, ampulla and vas deferens, and finally the formation of the genital opening and differentiation of the copulatory organ (secondary sexual characteristic). Similarly, the development of the female genital apparatus begins with the formation of the ovaries, followed by the appearance of oocytes in vitellogenesis, then the development of oviducts and uterus internus and, finally, the spermatheca. These data may be very important in further comparative studies on the development of the reproductive system of spiders.
\end{abstract}

Keywords: brown spider, reproductive system, post-embryonic development.

\section{Desenvolvimento do trato genital de Loxosceles intermedia Mello-Leitão (1934) (Aranea: Sicariidae)}

\begin{abstract}
Resumo
Examinamos o desenvolvimento pós-embrionário do aparelho genital masculino e feminino da aranha-marrom Loxosceles intermedia. O desenvolvimento do aparelho genital de ambos os sexos começa com o aparecimento de estruturas internas. No aparelho genital masculino a formação dos testículos ocorre primeiro, seguida pela diferenciação do ducto, ampola e vas deferens e, finalmente, a formação da abertura genital e diferenciação do órgão copulador (característica sexual secundária). Da mesma forma, o desenvolvimento do aparelho genital feminino começa com a formação dos ovários, seguida pelo aparecimento de oócitos em vitelogênese, o desenvolvimento dos ovidutos e uterus internus e, finalmente, a espermateca. Esses dados podem ser muito importantes em estudos comparativos sobre o desenvolvimento do sistema reprodutivo de aranhas.
\end{abstract}

Palavras-chave: aranha marrom, sistema reprodutor, desenvolvimento pós-embrionário.

\section{Introduction}

The brown spider Loxosceles intermedia Mello-Leitão (1934) (Araneae, Sicariidae) is a poisonous species found in the south of Brazil, predominantly in Paraná state, mainly in Curitiba city and neighbouring regions. In these regions, $L$. intermedia is widespread in human domestic habitats and its bite causes a public health problem known as loxoscelism (Fischer, 1994; Fischer and VasconcellosNeto, 2005a; Marques-da-Silva et al., 2006).

Effort has been made to decrease the incidence of loxoscelism and the search for effective treatment is constant. Important contributions toward achieving this goal could come from studies of $L$. intermedia development and biological reproduction processes.
There are consistent descriptions of the genital apparatus morphology in adult L. intermedia and other spider species (Alberti, 1991; Uhl, 2000; Uhl and Gunnarsson, 2001; Klann et al., 2005; Costa-Ayub and Faraco, 2007; Burger et al., 2006a, 2006b; Burger and Kropf, 2007; Talarico et al., 2008; Simeó et al., 2009).

In adult females of $L$. intermedia, the genital apparatus consists of the uterus externus and two seminal receptacles with cul-de-sac morphology (spermathecae) and internal tubular structures that make up the ovaries, oviducts and a secretory uterus internus. The uterus externus is separate from the internal structures by projections that form a valve that makes the connections between internal structures, 
the spermatheca and the exterior via the genital opening (unpublished data). The genital apparatus of the adult male L. intermedia consists of a pair of long, cylindrical testes that are each connected to a long, coiled vas deferens by a thin duct and a large ampulla. The testis is covered by myoid-like cells and its wall is made up of two types of cells, the somatic and germinative lineage (spermatogonia, spermatocytes, spermatids and sperm cells). Somatic cells are large cells with a basal nucleus that are in contact with the basal lamina. They have many extensions, between which lie germinative lineage cells. The spermatogonia are present in the basal region of the germinative tissue and are in contact with somatic cells. Spermatocytes in different phases of meiosis are present, while spermatids and cysts of sperm cells (with initial spermatids, late spermatids and sperm cells) are located in the ad-luminal position of this tissue (Costa-Ayub and Faraco, 2007).

Although there are many descriptions of the adult genital apparatus, only one report was found in the literature about the development of the genital apparatus in spiders. This report describes the development of spermatozoa and seminal secretion in the young cellar spider Pholcus phalangioides (Araneae, Pholcidae) (Michalik and Uhl, 2005).

Clearly, the development of the genital apparatus of young spiders is poorly understood but it is necessary for understanding its reproductive behaviour. Particularly for L. intermedia, these studies are important to improve population control strategies to reduce loxoscelism in the southern states of Brazil.

In light of this, the goal of the present work was to perform morphological studies of the genital apparatus of young (female and male) brown spider L. intermedia using light microscopy. Aspects of the sexual maturity process are discussed to improve the comprehension of its reproductive success.

\section{Methods}

Loxosceles intermedia adult males and females were collected from houses in the cities of Ponta Grossa and Palmeira (25 $11^{\prime} 16^{\prime \prime} \mathrm{S}$ and $50^{\circ} 08^{\prime} 40^{\prime \prime} \mathrm{E}$ and $20^{\circ} 24^{\prime} 46^{\prime \prime} \mathrm{S}$ and $50^{\circ} 00^{\prime} 23^{\prime \prime}$ E, respectively), Paraná, Brazil.

These animals were placed in individual plastic pots and maintained under ambient conditions of temperature and humidity. Water and larvae of Tenebrio molitor were supplied twice a month.

In order to obtain juvenile animals in the early stages of development, adults were mated. After emergence from egg sac, the young animals were placed in individual plastic pots and received the same treatment as described for the adults. In addition, the animals were regularly monitored for the stages of molts.

Young spiders that had undergone three, four, five and six molts were selected. A random sorting of males and females was performed before the fifth molt due to absence of any sexual dimorphism in these stages of the development. Characteristics such as the presence of palps that had differentiated into copulatory organs and body shape were used as parameters to differentiate males and females after the sixth molt.

Prior observation of animals kept in our laboratory for the last three years allowed us to differentiate animals by sex based on the anatomical position of the palps after the fifth molt. These animals were separated into two groups: those in which the palps were close to the cephalothorax (as in adult males) were considered juvenile males (Figure 1), and those in which the palps were located a little more distant from the cephalothorax (as in adult females) were considered juvenile females.

Males that had undergone the sixth molt, corresponding to the presence of palps differentiated into copulatory
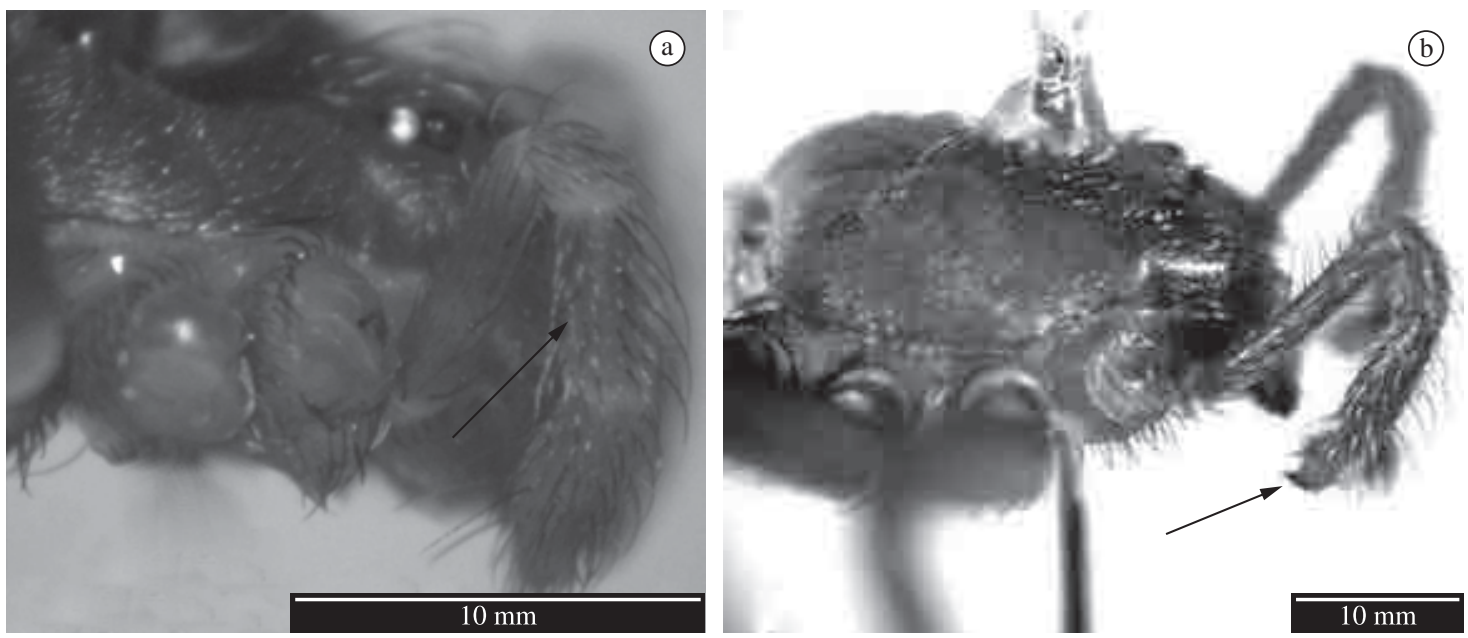

Figure 1. Position and morphology of the palps of male Loxosceles intermedia. a) Lateral view of the cephalothorax of an animal after the fifth molt. The arrow indicates one of the first pair of palps which already has its characteristic curved shape toward the ventral portion of the abdomen as is observed in adult males. b) Side view of the anterior portion of the cephalothorax of an animal after the sixth molt. The arrow indicates the copulatory bulb of one of the differentiated palps (pedipalp) with its characteristic anatomical position, i.e., curved toward the ventral portion of the abdomen. 
organs, were housed with females in order to observe whether the animals in this phase of the development already demonstrated mating behaviour, which would demonstrate their sexual maturity.

Specimens of females and males were obtained for each stage of development examined (third and fourth molts for females, and fourth and fifth molts for males). Females after the fifth molt and males after the sixth molt were not analysed because it has previously been observed that the main events of the differentiation process of internal genital apparatus occur between the fourth and fifth molts (fifth instar) and between the fifth and sixth molts (sixth instar), respectively. Animals were then selected in different stages during the fifth instar (females) and sixth instar (males) in order to improve the understanding of the morphological alterations involved in these processes. The selected females after the fourth molt were classified into early and late fourth molt while the males after the fifth molt were classified into early and late fifth molt. The nomenclature of the developmental stages mentioned above is based on Foelix (1996).

The selected animals were etherized and their abdomens were dissected and fixed in $4 \%$ paraformaldehyde in $0.1 \mathrm{M}$ phosphate buffer, $\mathrm{pH} 7.4$, for 2 hours at room temperature. Subsequently, the tissues were dehydrated in alcoholic series and embedded in historesin. Five micrometer serial sections were obtained and stained with hematoxylin and eosin (HE) or submitted to Periodic acid-Schiff (PAS) reaction for detection of neutral carbohydrates. The analysis of the ovaries followed the description of Morishita et al. (2003).

All histological preparations were photo documented under light microscope and analysed.

The published descriptions about genital system of adult female (Morishita et al. 2003) and male L. intermedia (Costa-Ayub and Faraco, 2007) were used as a model for all histological analyses of the same structures in the young stages of L. intermedia investigated in the present work.

\section{Results}

\subsection{Morphological description of the male genital apparatus}

The genital openings of young males after the fourth molt are still closed. Their palps are undifferentiated, and it is not possible to distinguish them from females. The testes, without a clear lumen, appear composed of germinative tissue (Figure 2a), but meiosis has not demonstrably begun. Each testicle is surrounded by a layer of flattened cells, the myoid cells (Figure 2b). The segments of the duct, the ampulla and the vas deferens have no morphological difference, appearing as a long and narrow string of cells extending from the testicle to the genital slit. At this stage of development, secretory activity by the tissues of the testis, the ampulla and the vas deferens was not observed.

Young male animals after the fifth molt were selected based on anatomical position of the palps. Their palps are positioned very closely to the cephalothorax, quite similar
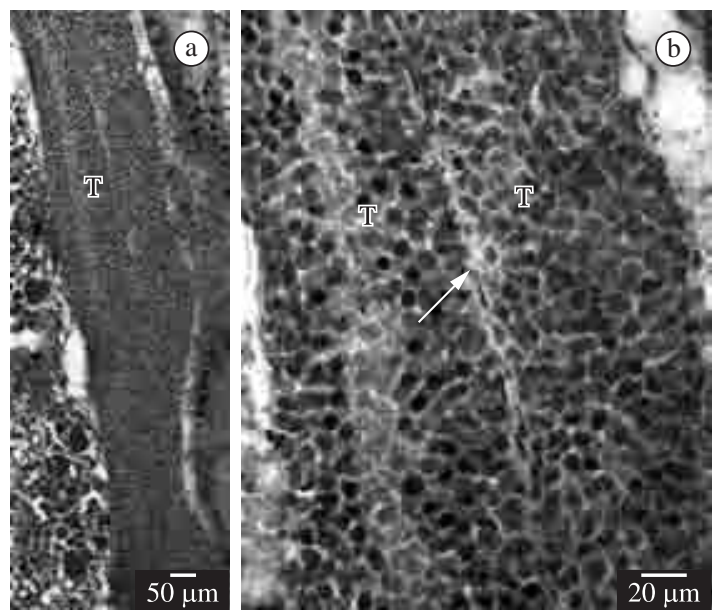

Figure 2. Longitudinal section of the abdomen of male Loxosceles intermedia after the fourth molt. Light microscopy and H.E. staining. a) The testes are arranged longitudinally to the plane of the section. It is not possible to observe their lumen. b) Portion of the testis showing the flattened myoid cells (arrow). No spermatogenic activity in the germ cells was observed. T: testis.

to in adult males, which led to an early identification of young males (Figure 1a). In animals that have just undergone the fifth molt (early fifth molt), testicular tissue does not yet show germ cells that have begun the process of spermatogenesis. The ampulla and vas deferens are morphologically individualised and the initial formation of their lumen can be observed in this phase. The duct also is morphologically differentiated but without a visible lumen. The genital slit has already opened and the ejaculatory canal lumen is in the process of formation. Animals in a more advanced stage of the fifth molt (late fifth molt) show some germ cells undergoing meiosis in their testes tissue, as well as some synspermia inside its lumen, indicating the start of the spermatogenesis. However, little secretory activity into the testis lumen can be detected (Figure 3a). The duct does not have an apparent lumen. The ampulla is still in formation (Figure 3b) and the final portion of the vas deferens has a narrow lumen (Figure 3c). Some individuals in the same stage of the development show more activity in the testes. These individuals have testes in active spermatogenesis, with a great number of germ cells undergoing meiosis and spermatids in the process of differentiation. The lumen of the testis contains more synspermia and an increase in its secretory activity is also evident (Figure 4a). The ampulla and the vas deferens lumen have completely opened. The presence of synspermia accumulated in the ampulla could be observed. Large amounts of synspermia are observed through the vas deferens. Little secretory activity was observed in the ampulla, but it was possible to note the presence of a large concentration of glycoprotein secretion in the region of the vas deferens. The tissue of the duct shows a single layer of juxtaposed cylindrical cells (Figures 4b-d). 

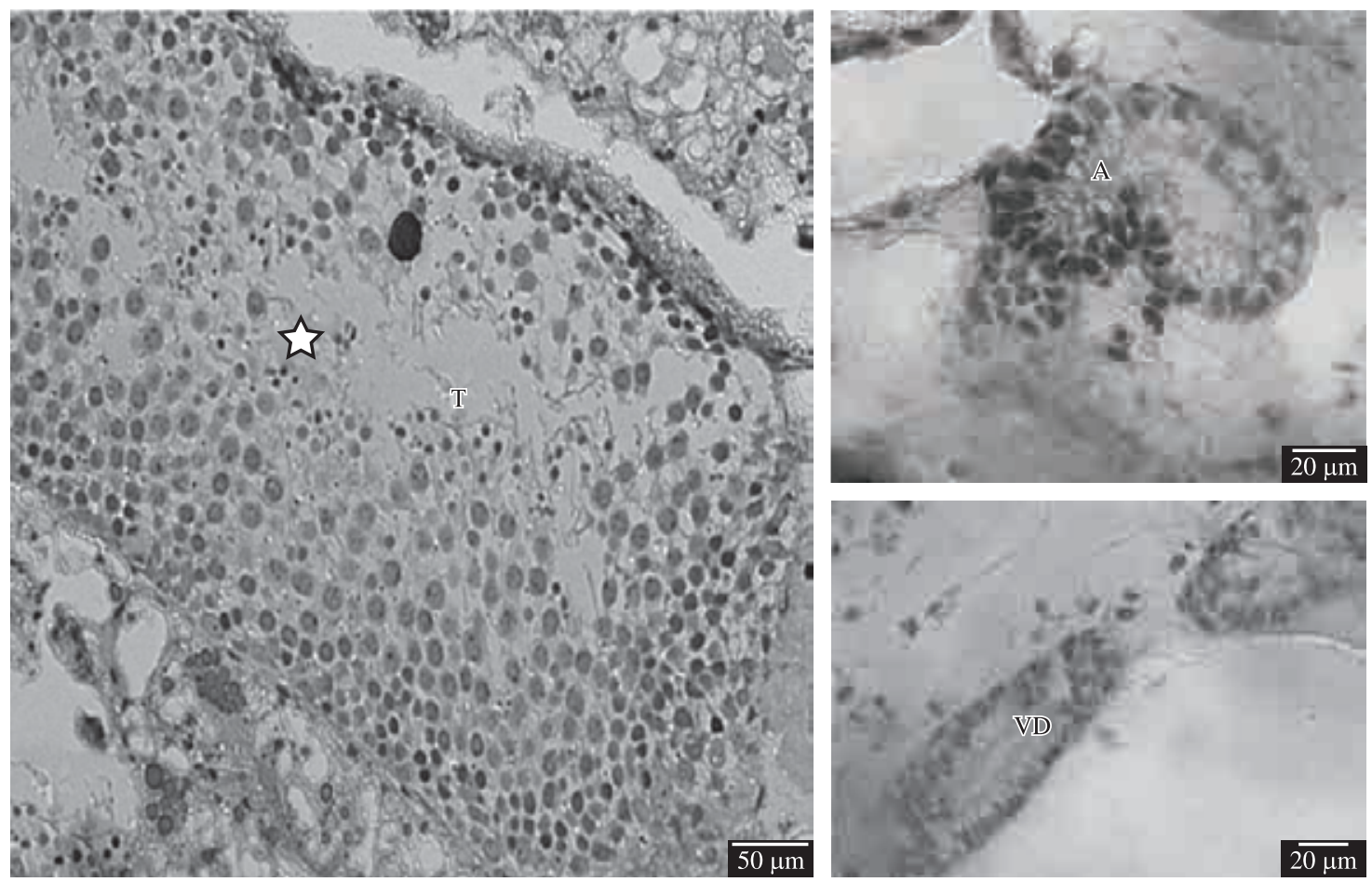

Figure 3. Longitudinal section of the abdomen of male Loxosceles intermedia in an advanced stage of the fifth molt (late fifth molt). Light microscopy and H.E. staining. a) The testis presents an evident lumen and cells undergoing spermatogenesis. Note the presence of secretion (*) in this segment. b) Portion of the ampulla in process of lumen formation. c) Portion of the vas deferens with cells delimitating a narrow lumen. T: testis; A: ampulla; VD: vasa deferentia.

Palps that were differentiated into copulatory bulbs (Figure 1b) were observed in males after the sixth molt. These specimens respond to female presence and show mating behaviour, which demonstrates their sexual maturity.

\subsection{Morphological description of the female genital apparatus}

Animals that have undergone the third molt have ovaries with only pre-vitellogenic oocytes. Their oviducts and uterus internus appear as two cords of cells without apparent lumen. The spermatheca is nothing more than a bud of gland developing from the wall of the uterus externus. The genital slit is somewhat chitinised and its opening is not yet apparent (Figure 5).

Animals in the early fourth molt stage have ovaries with oocytes in early vitellogenesis, but the cells of the oviduct do not yet have a lumen (Figure 6a). The same morphological aspects described for animals after the third molt are observed for the uterus internus and the spermathecae, which still appears as small glandular bud (Figure 6b). The uterus externus exhibits a deep cavity and the valve region appears completely closed. The genital slit of these animals is more chitinised in comparison with younger female spiders and its opening is already evident. In the late fourth molt stage, females present ovaries with oocytes in the process of vitellogenesis. Their oviducts and uterus internus show an evident lumen filled with secretion granules (Figure 7a). The spermatheca is fully formed and presents an evident and chitinised duct, with rare observation of some visible secretion inside it. The spermatheca wall is composed of uniform tissue. It is not yet possible to distinguish mucosal secretory cells in the glandular units (Figure 7b). The genital opening presents as quite chitinised and the uterus externus lumen is evident along its entire length (Figure 7c).

\section{Discussion}

This work provides unprecedented information on the ontogeny of $L$. intermedia at the morphological level, specifically concerning the development of the genital apparatus for males and females specimens in order to begin to answer the following questions: 1) Is there evidence of sexual dimorphism in young males prior to the sixth molt? 2) Does the presence of the pedipalp (an adult sexual characteristic) really indicate male sexual maturity? 3) How do the internal sexual organs develop in these animals? 4) Is there a synchronism between the development of the gonads and sexual ducts? 5) Does this development occur in the same way for males and females?

The observations in young males firstly related in the present work show evidence of sexual dimorphism prior to the sixth molt. This conclusion emerged from the observation of an important aspect of the external genitalia, the anatomical position of the palp, i.e., arched toward the abdomen, which is characteristic of the adult male, in 

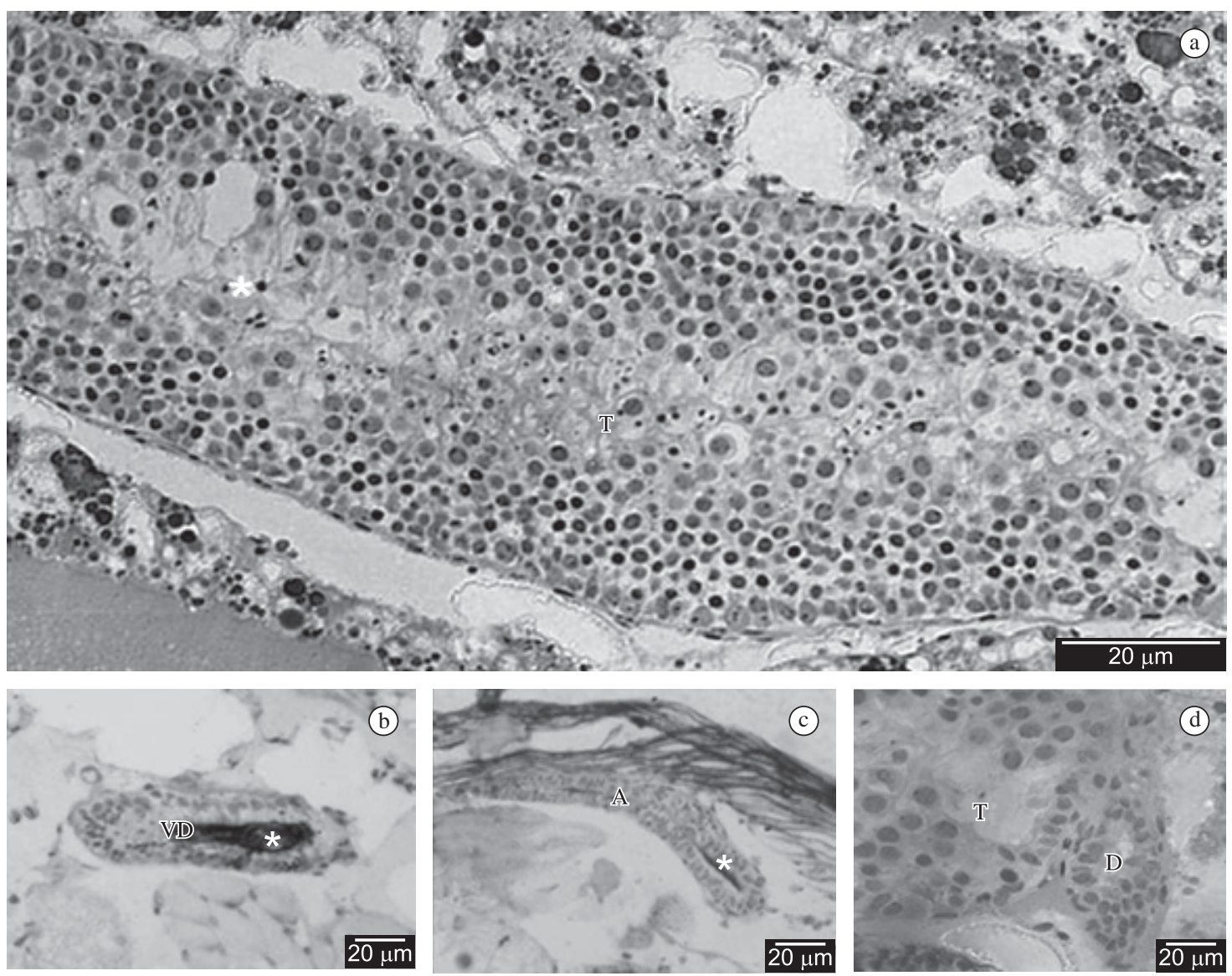

Figure 4. Longitudinal section of the abdomen of some individual male Loxosceles intermedia in an advanced stage of the fifth molt (late fifth molt). Light microscopy and Periodic acid-Schiff (PAS) reaction. a) Portion of the testis where an increase in the spermatogenic activity of the germ cells is noticed. Note also an increase of the secretory activity (*). b) Portion of the ampulla where a mass synspermia surrounded by secretion could be noted $(*)$. c) Portion of the vas deferens where a narrow lumen full of glycoprotein secretion could be seen $(*)$. d) Distal portion of the testis attached to the proximal portion of the duct. The duct is composed by a single layer of cylindrical cells without an evident lumen. T: testis; A: ampulla; VD: vasa deferentia; D: duct.

animals that had not yet undergone the sixth molt, contrary to the descriptions of Fischer and Vasconcellos-Neto (2005b) that consider sexual dimorphism in L. intermedia occurring after the sixth molt, when it is possible to visualise the copulatory bulb. It is probable that animals with the copulatory bulb already apparent are apt for reproduction (a question previously raised by us), but it seems that the finalisation of the development of the internal structures occurs after the first indications of a sexual dimorfism in this species. The possibility of earlier distinction between males and females of $L$. intermedia presented here is crucial information for studies on reproduction that could contribute to further investigations regarding population management of this venomous species in the urban environment.

Males with six molts demonstrated mating behaviour when in the presence of adult females, according to that previously described for the L. intermedia adult male (Fischer and Vasconcellos-Neto, 2000) which proves that they really have the ability to reproduce, i.e., are sexually mature. Consequently, their genital apparatus must show considerable spermatogenesis rates inside testes, large synspermia production and its accumulation within the ampulla and vasa deferentia, as demonstrated in the present work.

The results here presented demonstrate that the maturation of the internal male genital organs of L. intermedia is established during the sixth instar. By this developmental point in time, various stages of spermatogenesis and secretory activity can be visualised in the testis, despite the fact that adult body size and differentiation of palps into copulatory organs occur mainly during the seventh instar (Fisher-Vasconcellos-Neto 2005b). Secretory activity is also evident in the vas deferens and in the ampulla in individuals after five molts. In addition, the change in anatomical position of the palp observed in animals that had not undergone the sixth molt is indicative that the 
differentiation of the copulatory organs begins concomitantly with spermatogenesis in the testis.

Spermatogenesis in L. intermedia is shown to be continuous in the adult phase, since cells undergoing meiosis and spermiogenesis are visualised within the testicular tissue. A greater secretory activity of the testis, vas deferens and ampulla is also observed in adult male animals (Costa-Ayub and Faraco, 2007). These data are in accordance with descriptions in the literature for species

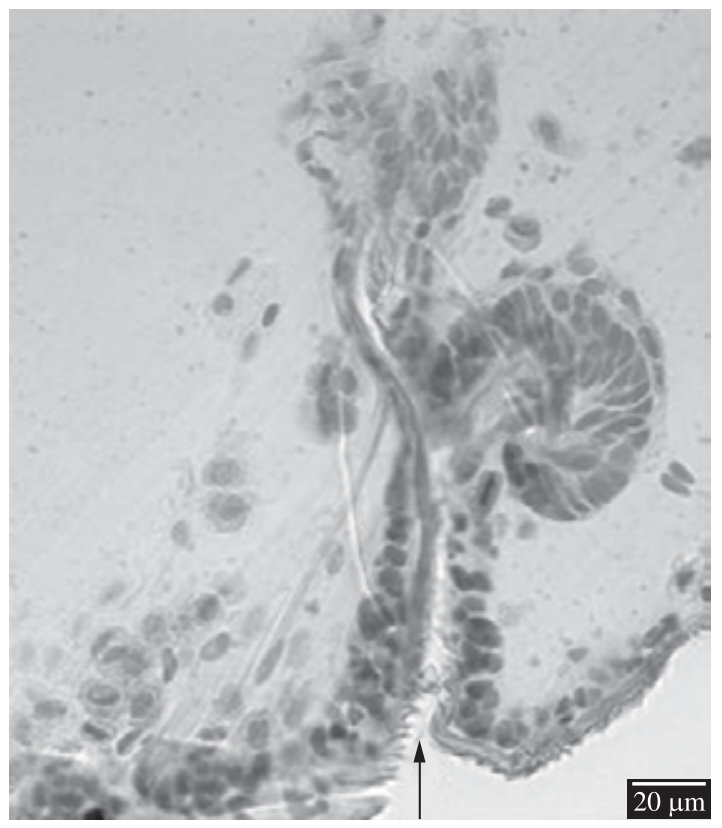

Figure 5. Longitudinal section of the abdomen of female Loxosceles intermedia after the third molt. The arrowhead indicates the slightly chitinised genital slit whose opening is not apparent yet. The spermatheca appears as a bud of gland which extends from the epithelial tissue. ST: spermatheca. with a long lifespan that copulate many times, as is the case for L. intermedia (Michalik and Uhl, 2005).

By contrast, the unique description of the development of spider genital apparatus in the literature (Michalik and Uhl, 2005) shows that the spermatogenesis process in Pholcus phalangioides (Araneae, Pholcidae) begins only a few weeks before the molt that precedes the adult formation. Therefore, the maturation of the internal male genital organs is delayed compared to L. intermedia maturation observed in this study.

In relation to the female $L$. intermedia reproductive system, the maturation of the internal genital organs occurs earlier than in the males. Specimens that have undergone only four molts have been observed to have pre-vitellogenic oocytes in the ovarian epithelium. The vitellogenic process normally begins during the fifth instar and reaches the adult pattern at the end of the seventh instar.

However, the passage of female L. intermedia to the adult phase occurs at the same time as the male (Fischer and Vasconcellos-Neto, 2005b) if one considers only external characteristics. According to these authors, the timing of sexual maturity could be related to a sexual selection system based on sperm cell priority in some spider species; that is, in species in which the sperm of the first male to mate with the female have priority in fertilisation, it is expected that they reach the adult phase (sexual maturity) early in order to maximise reproductive success. In spider species like L. intermedia, in which sperm cell priority is given to the last male to mate with a female, sexual maturity occurs at the same time in both sexes. Therefore, there is a synchronism between male and female $L$. intermedia in reaching sexual maturity assuming that this is the phase when the animals become suitable for mating. However, the observations at the morphological level of the internal genital apparatus show that the females start their development earlier than males and, therefore, take more time to reach sexual maturity. This could be
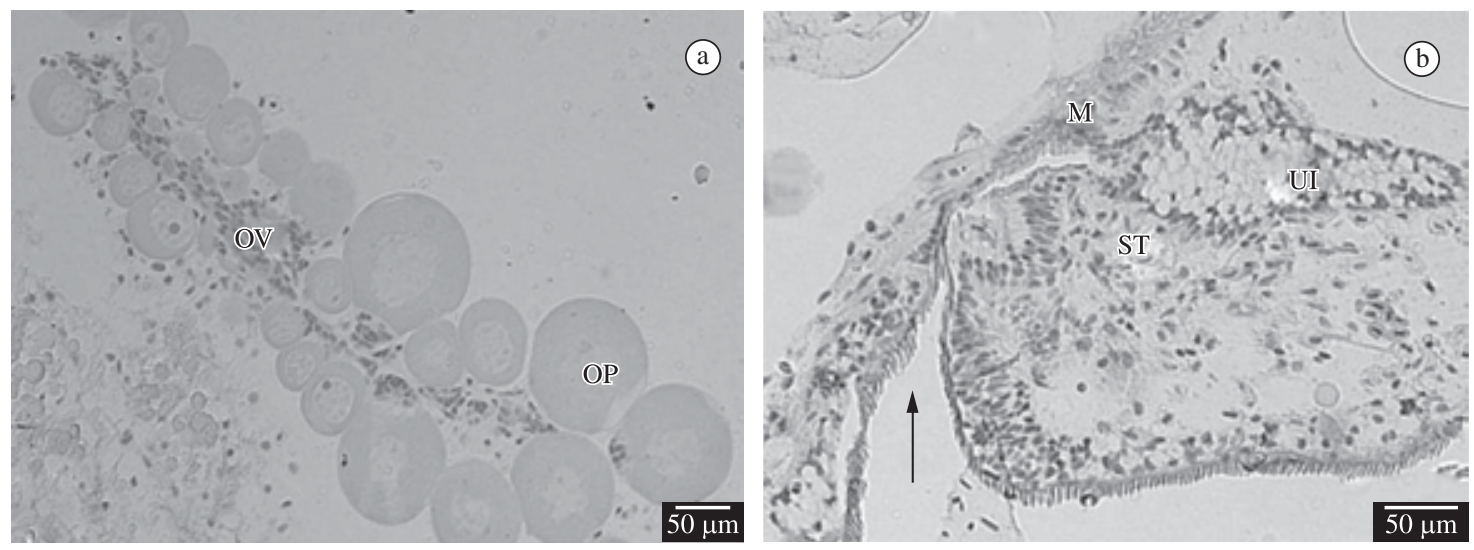

Figure 6. Longitudinal section of the abdomen of female Loxosceles intermedia at the early fourth molt stage. a) The oviduct is still closed but the ovary already shows pre-vitellogenic oocytes. b) The uterus internus is still closed and the spermatheca appears as a small glandular bud. The arrowhead indicates the genital slit still somewhat chitinized and its opening. OV: oviduct; OP: pre-vitellogenic oocyte; UI: uterus internus; ST: spermatheca; M: muscle. 

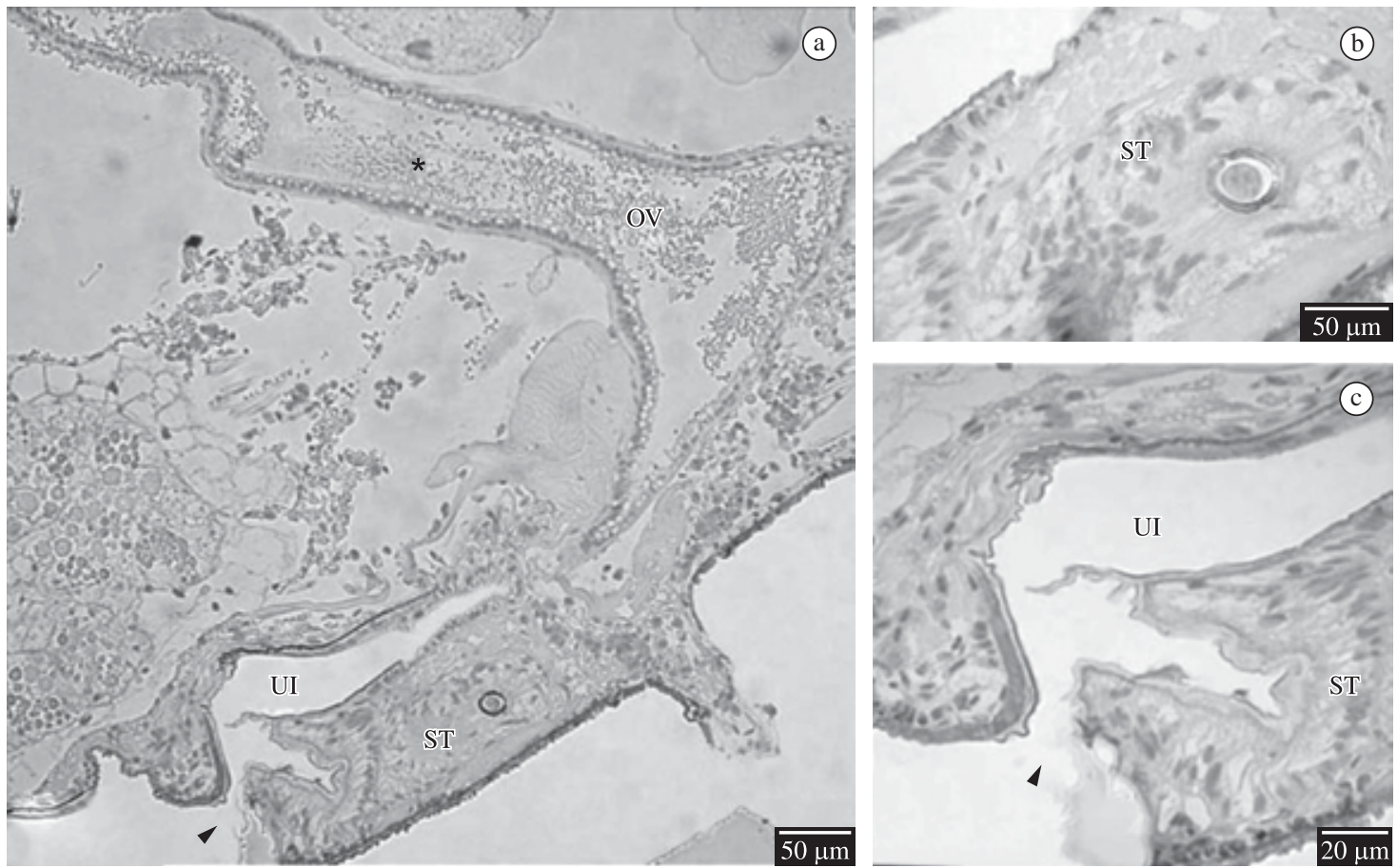

Figure 7. Longitudinal section of the abdomen of female Loxosceles intermedia at the late fourth molt stage. a) The spermatheca is elongated and fully developed. Uterus internus and oviduct are shown opened and filled with secretions $(*)$ and the genital slit is opened and well-chitinized (arrowhead). b) Detail of the spermatheca. c) Genital slit where the chitinised genital opening could be observed (arrowhead). The spermathecae and uterus internus are opened. OV: oviduct; UI: uterus internus; ST: spermatheca.

explained by the fact that the vitellogenic process is longer than the sperm cell differentiation process.

Another observation is that there are similarities in the mechanisms of development of the genital apparatus in males and females, since in both sexes the process starts with gonadal development and subsequent commencement of sexual ducts, culminating with the differentiation of the secondary sexual characters.

The data presented here reveal also that the process of sexual maturation in $L$. intermedia involves many stages, such as the formation of internal genital organs, establishment of adult body size and shape and differentiation of copulatory organs. It is clear that the development of internal structures is the first event to take place in both sexes. So why, in this representative of the Loxosceles genus, the initial stages of sexual maturity are fairly separate from the adult phase is a relevant question to explore in further studies. The data and results presented in this work clarify some aspects in the reproductive life of these group of organisms. Other spider genus or species which present different sexual selection mechanisms and/ or mating systems must be investigated with the aim of reinforcing the aspects in the reproductive life of this group of organisms observed here. These observations should stimulate discussion about the transition from young to adult, and its role in the divergent evolutionary strategies of spider reproduction.
Studies related to the development of the reproductive system in spiders are rare in the literature. Therefore, the present work contributes with data about the development of the male and female reproductive system of the brown spider $L$. intermedia that might be important for comparative studies and the comprehension of strategies of reproduction and adaptation in this species.

Acknowledgements - The authors thank Maria Inês Cordeiro for her dedicated technical assistance. Experiments described here were conducted in accordance with the current animal welfare laws of Brazil.

\section{References}

ALBERTI, G. and COYLE, FA., 1991. Ultrastructure of the primary male genital system, spermatozoa, and spermiogenesis of Hypochilus pococki (Araneae, hypochilidae). The Journal of Arachnology, vol. 19, p. 136-149.

BURGER, M., MICHALIK, P., GRABER W., JACOB, A., NENTWIG, W. and KROPF, C., 2006a. Complex genital system of a haplogyne spider (Arachnida, Araneae, Tetrablemmidae) indicates internal fertilization and full female control over transferred sperm. Journal of Morphology, vol. 267, p. 166-186. PMid:16276493. http://dx.doi.org/10.1002/jmor.10394

BURGER, M., GRABER W., MICHALIK, P. and KROPF, C., 2006b. Silhouettella loricatula (Arachnida, Araneae, Oonopidae): A Haplogyne Spider With Complex Female Genitalia. Journal 
of Morphology, vol. 267, p. 663-677. PMid:16502412. http:// dx.doi.org/10.1002/jmor.10435

BURGUER, M. and KROPF, C., 2007. Genital morphology of the haplogyne spider Harpactea lepida (Arachnida, Araneae, Dysderidae). Zoomorphology, vol. 126, p. 45-52. http://dx.doi. org/10.1007/s00435-007-0029-1

COSTA-AYUB, CLS. and FARACO, CD., 2007. Ultraestructural aspects of spermiogenesis and synspermia in the brown spider Loxosceles intermedia (Araneae: Sicariidae). Arthropod Structure and Development, vol. 36, p. 41-51. http://dx.doi.org/10.1016/j. asd.2006.07.004

FISCHER, ML., 1994. Levantamento das espécies do gênero Loxosceles Heinecken and Lowe, 1832 no município de Curitiba, Paraná, Brasil. Estudos de Biologia, vol. 3, p. 66-86.

FISCHER, ML. and VASCONCELLOS-NETO, J., 2005a. Microhabitats occupied by Loxosceles intermedia and Loxosceles laeta (Araneae: Sicariidae) in Curitiba, Paraná, Brazilian. Journal of Medical Entomology, vol. 43, p.756-65.

-, 2005b. Development and life tables of Loxosceles intermedia Mello-Leitão 1934 (Araneae: Sicariidae). Journal of Arachnology, vol. 33, p. 758-766. http://dx.doi.org/10.1636/S03-39.1

-, 2000. Comportamento sexual de Loxosceles intermedia Mello-Leitão, 1931 (Araneae, Sicariidae). Revista de Etologia, vol. 2, p. 31-42.

FOELIX, RF., 1996. Biology of the Spiders. 2nd ed. New York: Oxford University Press. 336 p.

KLANN, AE., PERETTI, AV. and ALBERTI, G., 2005. Ultrastructure of male genital system and spermatozoa of a Mexican camel-spider of the Eremobates pallipes species group (Arachnida, solifugae). The Journal of Arachnology, vol. 33, p. 613-621. http://dx.doi.org/10.1636/04-111.1

MARQUES-DA-SILVA, E., SANTOS, RS., FISCHER, ML. and RÚBIO, G., 2006. Loxosceles spider bites in the state of
Paraná, Brazil: 1993-2000. Journal of Venomous Animals and Toxins, vol. 12, p. 110-123.

MELLO-LEITÃO, CF., 1934. Espécies brasileiras do gênero Loxosceles lowe. Annaes da Academia Brasileira de Sciencias, vol. 6, p. 69-73.

MICHALIK, P. and UHL, G., 2005. The male genital system of the cellar spider Pholcus phalangioides (Fuesslin, 1775) (Pholcidae, Araneae): development of spermatozoa and seminal secretion. Frontiers in Zoology, vol. 2, p. 1-12. PMid:15987506. PMCid:1182384. http://dx.doi.org/10.1186/1742-9994-2-12

MORISHITA, R., FERREIRA, SA., SANTIAGO-FILHA, A. and FARACO, CD., 2003. Studies on Oogenesis and Oviposition in the Brown Spider Loxosceles intermedia (Araneae: Sicariidae). The Anatomical Record, vol. 273, p. 575-582. PMid:12808642. http://dx.doi.org/10.1002/ar.a.10062

SIMEÓ, CG., RIBESB, E. and ROTLLANT, G., 2009. Internal anatomy and ultrastructure of the male reproductive system of the spider crab Maja brachydactyla (Decapoda: Brachyura). Tissue and Cell, vol. 41, p. 345-361. PMid:19342069. http://dx.doi. org/10.1016/j.tice.2009.02.002

TALARICO, G., GARCÍA HERNÁNDEZ, LF. and MICHALIK, P., 2008. The male genital system of the New World Ricinulei (Arachnida): Ultrasctructure of spermatozoa and spermiogenesis with special emphasis on its phylogenetic implications. Arthropod Structure and Development, vol. 37, p. 396-409. http://dx.doi. org/10.1016/j.asd.2008.01.006

UHL, G., 2000. Female genital morphology and sperm priority patterns in spiders (Araneae). European Arachnology, p. 145-146.

UHL, G. and GUNNARSSON, B., 2001. Female genitalia in Pityhyplantes phrygianus, a spider with a skewed sex ratio. Journal of Zoology (London), vol. 255, p. 367-376. http://dx.doi. org/10.1017/S0952836901001467 